\title{
Translation Theory 'Translated': Three Perspectives on Translation in Organizational Research
}

Arild Wæraas and Jeppe Agger Nielsen 


\title{
Translation Theory 'Translated': Three Perspectives on Translation in Organizational Research
}

\author{
Arild Wæraas \\ School of Economics and Business \\ Norwegian University of Life Sciences \\ Christian M. Falsens vei 18 \\ 1432 Ås \\ Norway \\ e-mail: arild.waraas@nmbu.no \\ tel.: +4767231152 \\ Jeppe Agger Nielsen \\ Department of Political Science \\ Aalborg University \\ Fibigerstræde 1 \\ 9220 Aalborg \\ Denmark \\ e-mail: agger@dps.aau.dk \\ phone: 004599408212
}

\begin{abstract}
Translation theory has proved to be a versatile analytical lens used by scholars working from different traditions. On the basis of a systematic literature review, this study adds to our understanding of the 'translations' of translation theory by identifying the distinguishing features of the most common theoretical approaches to translation within the organization and management discipline: actor-network theory, knowledge-based theory, and Scandinavian institutionalism. Although each of these approaches already has borne much fruit in research, the literature is diverse and somewhat fragmented, but also overlapping. We discuss the ways in which the three versions of translation theory may be combined and enrich each other so as to inform future research, thereby offering a more complete understanding of translation in and across organizational settings.
\end{abstract}

\section{Acknowledgements}

An early version of this paper was presented on December 16, 2014 at the Center for Organization, Management and Administration at Aalborg University, Denmark. We thank Janne Seemann, Morten Balle Hansen, Gitte Tjörnhøj, and Jannie Kristine Bang Kristensen for detailed and constructive feedback on our paper. We also want to thank Silvia Gherardi, Tor Hernes, Susanne Boch Waldorff, and Turid Moldenæs as well as the three anonymous reviewers for their constructive comments on our work. Finally we thank Tine Rolstad Elvevold for technical help. 


\section{INTRODUCTION}

To apply a 'translation perspective' or rely on 'translation theory' is not the exclusive prerogative of any single group of academic community. Within organization and management disciplines, translation theory is used by scholars working from institutional theory (Czarniawska and Sevón, 2005b; Gondo and Amis, 2013; Lok, 2011; Maguire and Hardy, 2009; Waldorff, 2013a), actor-network theory (Alcouffe, Berland and Levant, 2008; Bergström and Diedrich, 2011; Greener, 2006; Hernes, 2005; Kelemen, 2000), and theories of knowing and learning and knowledge management (Bresman, 2013; Carlile, 2004; Gherardi and Nicolini, 2000; Sturdy, 2009; Thorpe, Eden, Bessant and Ellwood, 2011; Yanow, 2004). This broad dissemination of translation theory undoubtedly signals a vibrant and growing research field. However, given the fundamental notion of translation theory that "to set something in a new place is to construct it anew" (Czarniawska and Sevón, 2005b, p. 8), some variation concerning how translation theory is used across different communities of organization and management research is to be expected. This variation, which is our focus in this paper, is thus far not well understood. Is translation conceptualized and defined in the same way? Do contributions within these communities examine the same phenomenon? What are the differences and similarities between them?

As translation research within organization studies has entered its third decade, it is time to take stock of the most common approaches and further contribute to our understanding of their similarities and differences. This paper seeks to make two contributions to translation research. First, through a systematic literature study we identify and review the distinguishing features of three perspectives on translation 
within organization research; studies rooted in actor-network theory, knowledge-based theory, and Scandinavian institutionalism, respectively. To date, only a few scholars have produced reviews of translation research within specific theoretical approaches and highlighted strengths and blank spots (e.g. Boxenbaum and Pedersen (2009), Sahlin and Wedlin (2008), and Scheuer (2008a) within Scandinavian institutionalism). Although these studies have added insights into the breadth of translation theory and research, no studies have, to our knowledge, conducted systematic literature reviews on the basis of established criteria (as suggested by, for example, Tranfield, Denyer and Smart, 2003) of current translation literature by comparing core perspectives and taking into account multiple approaches. Accordingly, our paper systematically reviews and contrasts the similarities and differences between three 'versions' of translation theory identified here. We seek to clarify where the perspectives overlap and where they differ concerning research focus and theory application, critically considering their insights and limitations.

The second contribution of this paper follows from a key limitation we identify in our review: Translation research in organization studies is currently far from being a cumulative science where authors build on each other's findings and theoretical propositions. Even in a highly ranked journal such as Organization Studies, published papers seeking to contribute to translation research rarely refer to other papers on translation previously published in that same journal. ${ }^{1}$ Although the co-existence of multiple and sometimes competing perspectives is not unusual in academia, the general lack of cross-references and common 'language' is somewhat puzzling considering the fact that translation research in organization studies is a relatively young sub-discipline and the number of publications still fairly low. This, we argue, limits cross-fertilization and highlights the need for research that is guided by more than one perspective or, at 
least, positioned in relation to cognate understandings. As such, our review is a response to the call by Spyrionidis et al. (2014, p. 246) for research that seeks to clarify "how, if at all, can varying theoretical traditions be combined". We discuss potential ways in which the three versions of translation theory identified here may enrich each other so as to inform future research and offer a more complete understanding of translation in and across organizational settings.

In sum, the questions we pursue are the following:

1. What are the dominant theoretical perspectives on translation in organizational research and what are their distinguishing features?

2. How can these theoretical perspectives be combined so as to enrich our understanding of translation in organizational research?

The paper proceeds by introducing the origins of translation theory in organization research followed by a description of the method used for conducting the literature review. We then present findings from our review and synthesize knowledge from three different perspectives on translation. In discussion, we outline driving questions that motivate future organizational research, taking into consideration the benefits of applying and combining insights from the different perspectives. We conclude by summarizing the main contributions of our paper.

\section{TRANSLATION THEORY: ORIGINS}

The concept of translation in organization studies originates from the sociology of translation in actor-network theory. It was developed by French sociologists of science and technology Michel Callon (1986) and Bruno Latour (1986, 1987), who in turn received inspiration from Serres (1982) (Czarniawska and Sevón, 1996a, 2005b). 
Instead of understanding translation as an operation performed on languages, they conceptualized it as a complex process of negotiation during which meanings, claims, and interests change and gain ground. Translation thus has a political meaning, referring to the pursuit of interests or specific interpretations, frequently involving acts of persuasion, power plays, and strategic maneuvers (Nicolini, 2010). However, translation also has a geometric meaning. It encompasses the mobilization of human and non-human resources "in different directions", the result of which is "a slow movement from one place to another" (Latour, 1987, p. 117). Finally it has an important semiotic meaning, which concerns the transformation of meaning that occurs during the movement of the object in question.

Four stages are necessary in translation processes (Callon, 1986): Problematization, which is when actors offer problem statements and seek to convince others that they have the correct solutions; interessement, which corresponds to the strengthening of the links between the interests of various actors; enrolment, which refers to the participation of actors and their acceptance of their role in prioritizing a particular problematization; and mobilization, which concerns the maintenance of the network by ensuring that spokespersons act according to its interests. Translation, then, is a process of "creating convergences and homologies by relating things that were previously different" (Callon, 1980, p. 211).

For Latour, the question of how power is enabled, accepted, and diffused is an important focus area. In his model of translation, power is enabled if others choose to accept it; however they may translate the order of the person that holds power and change it "into something completely different as they [seek] to achieve their own goals" (Latour, 1986, p. 268, italics in original). Emphasizing the geometric and semiotic dimensions of translation, Latour notes that anything may spread in time and 
space in precisely this way including orders, claims, statements, and artifacts, resulting in "the faithful transmission of a statement [being] a single and unusual case among many, more likely, others" Latour (1986, p. 268). Thus, in contrast to Callon, Latour's model of translation assumes no end result of "convergences and homologies", but rather a process of "continuous transformation" (Latour, 1986, p. 268) resulting in a chain of unique translations depending on the distinct characteristics of the context.

It follows that Callon and Latour emphasize different aspects of translation, in particular concerning the outcomes of translation (for similar considerations see Czarniawska and Sevón (2005b, p. 8). Because subsequent research has addressed selected aspects of their contributions with some primarily emphasizing Callon's four moments of translation and others primarily emphasizing Latour's model of translation, the result is a range of theoretical statements. Thus, when organizational and management scholars began to use the concept from the 1990s and onwards, their inspiration came from Callon (e.g. Alcouffe et al., 2008; Bergström and Diedrich, 2011), from Latour (e.g. Gond and Boxenbaum, 2013; Røvik, 1998), from both (e.g. Bruce and Nyland, 2011; Frenkel, 2005), or seemingly from none of them (e.g. Bresman, 2013; Carlile, 2004). ${ }^{2}$ In sum, there is, and has been, a potential for "continuous transformation" of translation theory, resulting in multiple versions of translation theory across and within different research communities.

Still, these understandings do not exist simply by terminological coincidence. After describing our methodology for delimiting scholarly contributions within three perspectives on translation, we present their distinct characteristics and discuss how they, together, highlight the need for more systematic comparisons as well as combinations. 


\section{REVIEW METHOD}

We conducted a systematic literature review following well-established guidelines from Webster and Watson (2002), Tranfield et al. (2003), and MacPherson and Jones (2010). Accordingly, we have defined the boundaries of translation research in organization studies, we have used explicit criteria for inclusion and exclusion of contributions, and we have strived to make the review process transparent and reproducible. We have examined translation research up to and including August 2014. Our review includes articles as well as book chapters.

\section{Articles}

We began with all management journals with an impact factor of 1.0 or better as defined by Thomson ISI's rankings for 2012. From this list of 176 journals we removed journals from sub-fields such as engineering, psychology, nursing, area studies, supply chain, logistics, research methods, tourism, and so on, in order to maximize the coherence and relevance of the sample. We added two journals to the sample that did not meet the impact factor requirement: Scandinavian Journal of Management, because Scandinavian institutionalists are likely to publish translation research there; and Journal of Change Management, because of their special issue on "discourse, translation and change" in 2013. The final sample thus consisted of 75 journals.

To identify and retrieve the relevant articles from these journals, we relied on the Thomson ISI Web of Knowledge search engine and Proquest using queries that contained in the title, abstract, and keywords, at least one of the following keywords: “translation", "translating" and "organizational translation". This procedure generated 263 articles. From this list of articles we excluded those that (a) turned out to not use 
the concept of translation, and (b) used the concept of translation but did not build explicitly on translation theory of some sort; that is, they made reference to the chosen terms only in passing (i.e. "light citing") or used the notion of translation only as a synonym for change. We included articles that (a) relied on translation theory for a general theoretical discussion, or (b) applied translation theory to shed light on empirical data. By translation theory we mean, in this case, a presentation of a series of generalized and inter-related arguments concerning translation as a phenomenon in and across organizational settings, supported by references to previous works on translation. The application of these inclusion and exclusion criteria reduced the sample to 59 articles.

\section{Book chapters}

We first gathered all the books in the field of organization studies that we already knew included chapters on translation and added more chapters to our sample as we worked through the literature review. We subsequently searched book library databases using key words such as "translation", "translating" and "organizational translation" to crosscheck our sample. On the basis of a final sample of nine edited book volumes, we generated a list of 35 chapters. We classified each of them according to the following criteria: (1) chapters that do not use the concept of translation, (2) chapters that use the concept of translation but do not build explicitly on translation theory, (3) chapters that explain the concept of translation and/or translation theory (typically introductory chapters), and (4) chapters that rely on translation theory on empirical material or for a general theoretical discussion. For our review, we decided to include chapters from categories 3 and 4 to ensure the highest possible similarity with the selected journal articles. This procedure yielded a total of 22 book chapters. 


\section{Analysis}

Our analysis proceeded partly deductively, partly inductively, revealing quite quickly a tripartite division of perspectives. We identified many works written from the Scandinavian institutionalist perspective, as could be expected. However there was also a clear tendency for some works of relying on actor-network (ANT) literatures (e.g. Alcouffe et al., 2008; Bergström and Diedrich, 2011) and others of building on knowledge-based theory (e.g. Carlile, 2004; Yanow, 2004). We aimed to explore this theoretical division in more detail, proceeding by coding each contribution accordingly (see appendix). We ended up with 22 articles from the ANT perspective, eight from the knowledge-based perspective, and 20 articles from the Scandinavian institutionalist perspective. Furthermore, we identified 16 book chapters written on the basis of Scandinavian institutionalism, none using knowledge-based theory, and six chapters relying on ANT. We grouped into a separate 'residual' category, and analyzed separately, nine articles whose theoretical framework did not warrant classification into any of the three perspectives.

With a final sample of 72 works (50 articles and 22 book chapters), the last phase consisted of coding on the basis of standard criteria that can be adopted in a literature review to outline patterns found in the literature. In general, the choice should satisfy principles of relevance and of feasibility (Webster and Watson, 2002). Accordingly, we coded the selected articles based on (1) year of publication, (2) journal or book, (3) theory focus (i.e. actor network theory, knowledge-based theory, Scandinavian institutionalism, and others), (4) empirical focus (e.g. health care or banks), (5) objects of translation (e.g. ideas or interests), (6) definition of translation, and (7) key findings and/or arguments. Coding was performed independently by both 
authors on subsets of the sample followed by cross-checking, random checks, and recoding when our codes differed, until we had reached an agreement on all codes.

\section{Classifications}

Criteria that helped us classify a work as relying on either ANT, knowledge-based theory, and Scandinavian institutionalism, included the following:

(1) The work is a constitutive part of one of the theoretical approaches. This is the case with Czarniawska and colleagues' works (2009; 1996; 1996a, 2005b), which have been central in developing the Scandinavian institutionalist approach to translation.

(2) The work declares explicitly that it is building on one specific theoretical perspective or concepts that are central to it. For example, concerning the ANT approach, scholars state that "this paper is conceptually grounded on ANT" (Alcouffe et al., 2008, p. 2) or "we draw on actor-network theory" (Gond and Boxenbaum, 2013, p. 708). From the knowledge-based perspective, Merminod and Rowe (2012, p. 298) announce that "[t]his case study sheds light on how PLM [Product Lifecycle Management] facilitates knowledge transfer and translation practices" and Sturdy, Brocklehurst, Winstanley and Littlejohns (2006, p. 843) state that they seek to "point to the analytical value of exploring the translation of knowledge". Finally, works that are grouped under Scandinavian institutionalism include Kirkpatrick, Bullinger, Lega and Dent (2013, p. s48), who state that "[s]pecifically we use ideas from Scandinavian institutionalism", and Nielsen, Mathiassen and Newell (2014, p. 166) who inform that they "draw on Scandinavian institutionalism".

(3) The work concentrates its presentation of theory primarily around one of the three approaches, and most of the studies to which it refers also build on this approach. 
This is the case with works in edited volumes whose chapters share the same overarching approach, including Gherardi and Nicolini (2005), Hernes (2005) and Holmström and Robey (2005), which appear in Actor-Network Theory and Organizing (Czarniawska and Hernes, 2005), and Scheuer (2008a, b), which appear in the book The Anatomy of Change - a Neoinstitutional Perspective (Scheuer and Scheuer, 2008). It is also the case with a number of works that fulfill all inclusion criteria but have a preference for one of the approaches although not stating so directly. This comes to expression in two ways; through the definition or description of translation, and through the use of references. For works classified under the ANT perspective, definitions and descriptions tend to emphasize Callon or Latour's writings, with few or very few references to the studies reviewed here that are written from knowledge-based or Scandinavian institutionalist perspectives (see review further below). Conversely, works written from the knowledge-based perspective tend to rely on their own definitions and descriptions of translation, with no or almost no references to the ANT or Scandinavian institutionalist traditions. Finally, works relying on the Scandinavian institutionalist perspective tend to refer to Czarniawska and her works, as well as others in the Scandinavian tradition (e.g Røvik, 2011; Sahlin-Andersson, 1996) with no or almost no references to works from the ANT- and knowledge-based categories.

Thus, most of the works are classified within one of the three perspectives based on what we find to be the main theoretical approach. The nine works that are not classified within the three perspectives also build on translation theory, but do so in various ways not fully consistent with one particular perspective. Three of them mix core arguments from different perspectives (Bartel and Garud, 2009; Frenkel, 2005; Gherardi and Nicolini, 2000). Others develop their own approach or adopt translation theory to a new field (e.g. Clegg, Kornberger and Rhodes, 2004; Doolin et al., 2013; 
Mueller and Whittle, 2011). We return to the three works that combine approaches in the discussion section of this paper because they add important insights to the question of how the different perspectives may enrich each other.

\section{Limitations}

Our classification of translation research into three perspectives implies some simplification. It does not allow for as many nuances as would a review of only one perspective. This, however, must be balanced against the need for a more overarching approach that reveals multiple approaches and exposes the potential for crossfertilization, which is our concern in this paper.

Our classification also misses out of many works that do not fall within the three categories. For example, the translation concept appears in the fields of (linguistic) translation studies (e.g. Hatim and Munday, 2004), anthropology (e.g. Asad, 1986), medicine and health care (e.g. Straus, Tetroe and Graham, 2009), policy studies (e.g. Johnson and Hagström, 2005) and science and technology (e.g. Woolgar, Coopmans and Neyland, 2009). Although insights from these domains have some relevance for our project, they are excluded from this review because they are not written as contributions to organization research.

Furthermore, we recognize that there are a number of works within organization studies that deal with topics similar to the ones studied here. For example, the recent interest in understanding management ideas as viruses that have the capacity to 'infect' host organizations (Madsen and Slåtten, 2015; Quist and Hellström, 2012; Røvik, 2011) and the growing literature on 'glocalization' (Drori, Höllerer and Walgenbach, 2014) and practice variation (Ansari, Fiss and Zajac, 2010; Gondo and Amis, 2013; Saka, 2004), share notable features with translation research in the sense that the focus is on 
how, when, and why organizational practices vary as they spread in time and space. ${ }^{3}$ Even if some of these works position themselves in relation to translation theories (e.g. Saka, 2004), they are not included in this review because they do not aim to apply translation theory to a particular empirical case or for a general theoretical purpose.

A third limitation concerns our choice of inclusion and exclusion criteria. We recognize that other perspectives on translation than the ones identified by us may exist outside the 75 selected ISI-ranked journals. We also recognize that papers may have been published in journals without mentioning translation in the title or abstract, and that there are other valid outlets for translation research including online media, conference papers, and journals, including those with an impact factor lower than 1.0.

A final limitation is our exclusive dependence on English language journals. However, where appropriate, we refer to other works that we are able to read ourselves to complement our presentation of the perspectives. In sum, although we highlight only parts of the research on translation, we believe the chosen focus encompasses some of the most important parts, thereby offering both a rigorous and relevant portrayal of translation perspectives as they are presented in current organizational research.

\section{THREE 'TRANSLATIONS' OF TRANSLATION THEORY}

Key findings from our review are summarized in Figures 1a (articles) and b (articles and chapters combined) and in Table 1 at the end of this section. The figures illustrate a central aspect of the theoretical development of translation research since 1990: The ANT perspective was adopted into organizational research first, followed by knowledge-based theory and Scandinavian institutionalism perspectives. We also note a considerable growth of literature after the millennium shift and especially after 2004. 
Following the advice from Tranfield et al. (2003) we first provide a brief descriptive analysis using sets of categories such as year of publication and preferred research design. We then report the findings of a thematic analysis, which presents the main conceptualizations of translation. We apply this distinction for each perspective.
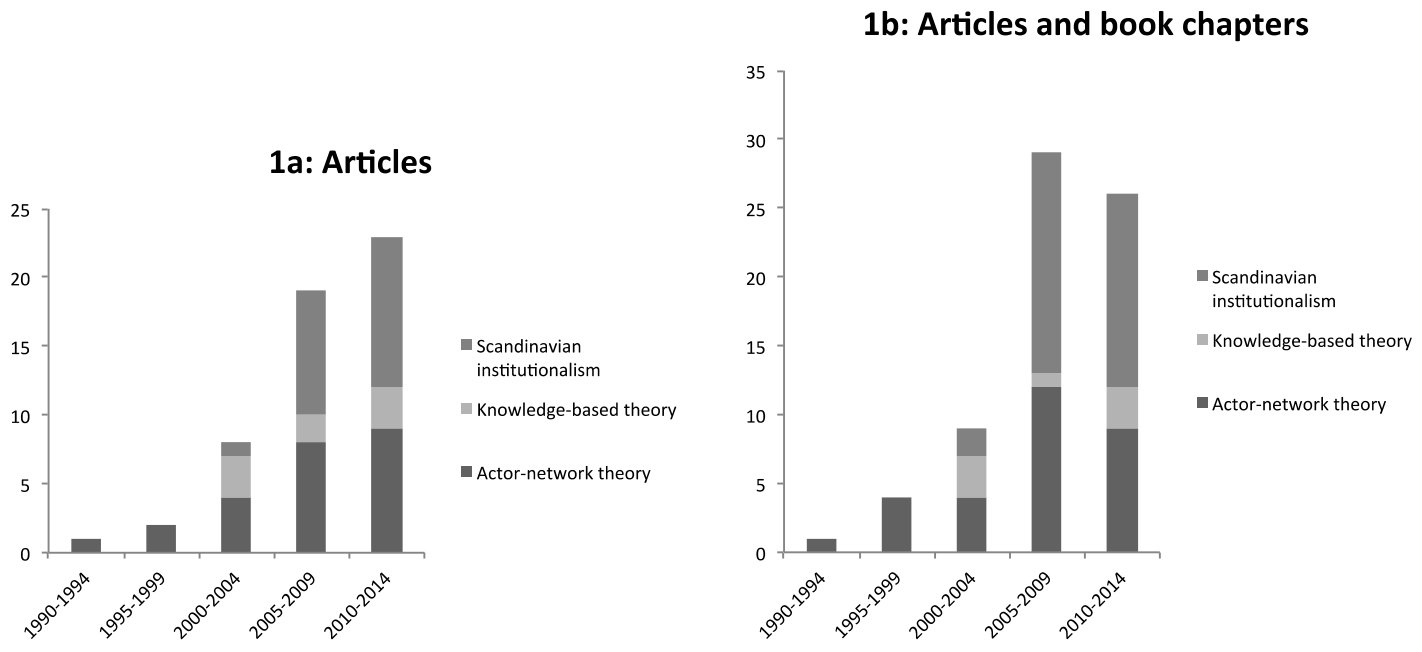

Figures 1a and b: Publication frequencies for each perspective.

\section{The Actor-Network Perspective}

The actor-network perspective within organization studies is an established literature. Books (e.g. Czarniawska and Hernes, 2005), journal articles (e.g. Calás and Smircich, 1999; Lee and Hassard, 1999; McLean and Hassard, 2004), and a special issue of Organization (volume 6, 1999) are evidence of a growing field. However, this literature does more than examine translation. Power relations (Knights, Murray and Willmott, 1993), innovation (Harrison and Laberge, 2002), technologies (Munir, 2004), and conflict (Dent, 2003) are only some of the topics on which the theory is applied, and without necessarily making translation an empirical object of study. 
The part of this literature that specifically addresses translation is the main focus here. This perspective was introduced to organization research in the early 1990s, a decade after Callon's first works on translation (Callon, 1980, 1986), but several years before the emergence of Scandinavian institutionalism and knowledge translation studies.

Descriptive analysis: A total of 28 works are included in this category; 22 articles and six book chapters. After the first contribution in our sample was published in 1991, the number of works increased steadily, as summarized in Figure 1. Seven articles appear in Accounting, Organization, and Society, while Organization and Organization Studies have three articles each. Other journals, including Scandinavian Journal of Management and Journal of Management Studies, have published one article each. Three book chapters are published in Actor-Network Theory and Organizing, edited by Czarniawska and Hernes (2005). The ANT approach largely inspires empirical work: Two contributions are conceptual while the 26 others present empirical data from case studies on the basis of qualitative research designs, nine of which employ observational methods. We also note that translation theory is not the only theory employed in the papers. A variety of other theories are integrated such as accounting theory (Alcouffe et al., 2008), entrepreneurship (Whitley, 1999), institutional work (Gond and Boxenbaum, 2013), and critical organization theory (Whittle and Spicer, 2008), to mention a few.

Thematic analysis: In the majority of actor-network accounts, the political and semiotic meanings of translation are evident: Translation occurs in a setting characterized by diverging or conflicting meanings and interests. Actors rely on various tactics, maneuvers, tricks, and discursive techniques to convince other actors to embrace a certain point of view (Bergström and Diedrich, 2011; Bruce and Nyland, 
2011; Chua, 1995; Greener, 2006; Kelemen, 2000). For example, Robson (1991, p. 550) conceptualizes translation as the process through which organizational practices "are articulated discursively in ways that construct individuals' and groups' "interest" in those techniques, and may subsequently provide motives for producing changes". Kelemen (2000, p. 495) notes that translation is about what top management does to seduce, force, or rationally convince employees through the use of language that a specific practice is "a viable and profitable option for everyone". More recently, Waldorff (2013a, p. 221) notes that translation "is about enrolling more and more micro-actors into a powerful network to build support for a specific claim and possibly make this claim into a taken-for-granted fact". Thus, translation is highly political and involves the mobilization of a network of actors supporting a particular claim or object, making it as permanent as possible. When doing so, processes of problematization (Maguire and Hardy, 2009; Robson, 1991), interessement (Alcouffe et al., 2008; Dambrin and Robson, 2011), enrolment (Alcouffe et al., 2008; Bergström and Diedrich, 2011), and mobilization (Bergström and Diedrich, 2011; Greener, 2006) are involved. The object of translation - that which is translated - is interests, claims, convictions, and meanings. With reference to this understanding, particularly Callon's (1986) work - and with hardly any positioning in relation to works written from the knowledgebased or Scandinavian institutionalist perspectives - scholars have investigated a range of issues pertaining to translation including their causes, drivers, and purposes (Chua, 1995; Kelemen, 2000; Mouritsen, Larsen and Bukh, 2001; Qu and Cooper, 2011), their effects and implications (Alcouffe et al., 2008; Jensen, Sandström and Helin, 2009; Maguire, Hardy and Lawrence, 2004), and processes (Greener, 2006; Hernes, 2005; Holmström and Robey, 2005; Vidgen and McMaster, 1996). 
In other, but fewer works, the geometric and semiotic dimensions of translation are more apparent. Translation is understood as a change process that occurs to a spreading construct. In this process, more than perceptions of a particular object or the interests of particular actors are at stake: Translation concerns the fate of management ideas, particularly with respect to intentional or unintentional modifications. For example, within the framework of the ANT perspective, Waldorff (2013a) understands translation as a process whereby actors mobilize meaning to turn an organizational innovation into local versions. Sahay, Sæbø and Braa (2013) build on Latour's model of translation to conceptualize translation as a process whereby spreading constructs acquire elements of difference, resulting from contextual forces working upon them, and leading to the diffusion process being "same, same, but different" (Sahay et al., 2013, p. 295, italics in original). Similarly, Jensen et al. (2009) note that translation means simplifying a construct so that something is "lost in translation" (Jensen et al., 2009 , p. 532, italics in original), but also that elements of the spreading construct are assembled into an actor-network where some actors have the power to translate the construct whereas others do not, resulting in "numerous translations..., all of which are travelling” (Jensen et al., 2009, p. 533). The shared characteristic of these contributions is the focus on a particular object that is travelling across different contexts. To translate something is to actively modify an object within the context and complexities of an actor network. This conceptualization is close to the standard understanding of translation in the Scandinavian institutionalist literature (see further below). On the basis of this understanding of translation, researchers have investigated a range of objects that travel into new contexts and acquire new meanings including corporate codes of ethics (Jensen et al., 2009), health care center concepts (Waldorff, 2013a), and international accounting standards (Mennicken, 2008), among others. 


\section{The Knowledge-Based Perspective}

Knowledge-based theory is, like the actor-network literature, an established field of research (Miles, 2012). A number of journals (e.g. Journal of Knowledge Management and Knowledge and Process Management, but also Management Learning) and conferences (e.g. International Conference on Organizational Learning, Knowledge and Capabilities and European Conference on Knowledge Management) are evidence of a large but heterogeneous field. Contributions are divided between those that consider knowledge mostly as a commodity that can be stored and replicated exactly or partially as a basis for competitive advantage, and those that primarily emphasize learning and the socially constructed nature of knowledge development (Chiva and Alegre, 2005; Easterby-Smith, Crossan and Nicolini, 2000). This division is also notable in works that consider knowledge translation. However, there is agreement that knowledge is essential for organizational survival, growth, and success.

A number of authors refer to knowledge translation mostly as a synonym or metaphor for knowledge transfer (Holden and Kortzfleisch, 2004). Recently, however, a small but growing number of authors accept knowledge translation as a phenomenon in its own right, opening up the possibility that knowledge may change its content, form, and appearance as it moves from one context to an other. In the following, we refer to this approach as the knowledge-based perspective on translation.

Descriptive analysis: Although knowledge-based theory encompasses a voluminous literature, works that examine translation from this specific perspective are rather scarce. The smallest category of translation in our review includes eight articles and no book chapters. Three of them are published after 2010, the others between 2004 and 2006 (Figure 1), all of which are published in highly ranked journals: Two articles 
appear in British Journal of Management, and two are published in journals that are related to information technology; MIS Quarterly and Information and Organization. The others are published in Academy of Management Journal, Organization, Management Decision, and Organization Science. Three papers are conceptual while the others rely on qualitative methods, using a combination of interviews, observations and document analysis, similar to works carried out under the ANT perspective. However, in contrast to the ANT perspective, works examining knowledge translation combine translation theory with other and fewer theories. Those that do integrate other theories focus on learning (Bresman, 2013; Pawlowski and Robey, 2004; Savory, 2006; Yanow, 2004) and identity work (Sturdy et al., 2006).

Thematic analysis: The knowledge-based perspective directs our attention to the concept of knowledge translation. Compared to the ANT perspective, a whole new vocabulary is employed: The focus is on key concepts such as source, target, recipient, boundaries, peripheries, and transfer. In most of the works, translation is portrayed as a boundary-spanning activity undertaken to ensure the effective flow of critical information and domain-specific knowledge across organizational boundaries. Merminod and Rowe (2012, p. 300) understand translation as a knowledge sharing process that "links two or more groups of people separated by location, hierarchy, or function", defining it as an activity that "involves sharing evolving objects that are minimally codified, and a semantic capacity for developing common meanings" (2012, p. 298). Bresman (2013, p. 36) defines translation as a process whereby "group members translate the identified knowledge into a vernacular that speaks to their own context”. Similarly, but more broadly, for Pawlowski and Robey (2004, p. 649), "translation involves framing the elements of one community's world view in terms of another community's world view." 
Different meaning systems resulting from different group, organizational, professional, and national cultures are assumed to limit the effective flow of knowledge. Knowledge translation, therefore, has strategic importance for an organization (Savory, 2006). The need to translate grows out of differences in the form of requirements or actors (Bresman, 2013) or appears when innovation is a concern (Carlile, 2004). In these cases, understanding the movement of knowledge simply as knowledge transfer from one place to an other is insufficient. Domain-specific knowledge cannot move effectively from one domain to the other without some sort of shared understanding of what the knowledge means in the recipient context (Bresman, 2013). Translation thus requires "bi-cultural translators", who have expert knowledge of multiple contexts (Yanow, 2004, p. s15) as well as organization-wide knowledge translation capability (Savory, 2006). Accordingly, the knowledge-based perspective attributes an important role in translation processes to brokers such as IT professionals (Pawlowski and Robey, 2004), border crossers or peripheral workers (Yanow, 2004), and project leaders and outsourcing engineers (Merminod and Rowe, 2012). These brokers operate at the interface between different contexts, both inside and outside the organization, moving back and forth and translating knowledge from donors (source context) to recipients (target context). Alternatively, the donor and the recipient deal directly with each other (Bresman, 2013; Thorpe et al., 2011).

Thus, a common concern in these accounts is the focus on the semiotic and geometric dimensions of translation. There are no references to works written from the ANT perspective concerning sociological issues of translation such as power, networks, persuasion, and politics, nor to any moment of translation. Indeed, translation is less controversial and political, in multiple accounts involving instead an instrumental focus on effectiveness both in terms of how translation may increase the effectiveness of 
knowledge management (Pawlowski and Robey, 2004), how knowledge translation effectiveness may be increased by other factors (Merminod and Rowe, 2012), and how knowledge translation capability solves problems and contributes to competitive advantage (Savory, 2006). Exceptions are Sturdy et al. (2006), who link translation to existential and emotional issues of individual identity work, and Yanow (2004), who links translation of local knowledge with organizational learning.

In sum, what separates these eight articles from the others is the focus on organizational knowledge as the object of translation. On the basis of this understanding, researchers have investigated translation in contexts of routine change (Bresman, 2013), researchers' impact on theory and practice (Thorpe et al., 2011), new product development (Merminod and Rowe, 2012), and professionals' use of management knowledge (Sturdy et al., 2006).

\section{The Scandinavian Institutionalist Perspective}

Depicted as one of the promising new directions of institutional thinking (Clegg, 2010; Greenwood, Oliver, Sahlin and Suddaby, 2008), Scandinavian institutionalism is an established field of research. Its origin is associated with Czarniawska and Sevón (1996b), who brought the notion of translation into institutional analysis as an alternative to diffusion models and decoupling scenarios developed by American institutionalists. From this point onwards, Scandinavian institutionalism has thoroughly discussed and investigated fashion, loose coupling, sense-making and translation (Boxenbaum and Pedersen, 2009). It stresses the circulation of ideas and practices as highly interactive following various routes and enabled by different "idea carriers" (Djelic and Sahlin-Andersson, 2006; Sahlin-Andersson and Engwall, 2002), and iteratively transformed as they are turned into local arrangements. In this way ideas and 
practices travel across social levels, shifting from being abstract ideas to objects with real existence (ideas transformed into objects) or enacted practices (ideas transformed into action).

Descriptive analysis: Overall, we identified 20 articles and 16 book chapters using this perspective. ${ }^{4}$ The first journal article in our sample was published in 2002 (Creed, Scully and Austin, 2002), after which the number of articles has increased dramatically (Figure 1). In contrast to the ANT and knowledge-based perspectives, Scandinavian Journal of Management is the most frequently used outlet (four articles). Organization Studies and Management Learning have three articles each, while other high-profile journals (e.g. Organization, Academy of Management Journal) have published one or two articles.

Edited book volumes are an important publication outlet for authors working from the Scandinavian perspective. The 16 chapters are found in seven different books, including Translating Organizational Change, as noted, and Global Ideas: How Ideas, Objects, and Practices Travel in the Global Economy, among others. While several book chapters are conceptual (e.g. Czarniawska and Joerges, 1996; Sahlin-Andersson, 1996; Sevón, 1996), this is the case with only one article (Gondo and Amis, 2013). The rest of the contributions are empirical, relying on qualitative research designs using single case studies (e.g. Høyer, 2009; Waldorff, 2013b) or multiple case studies (e.g. Kirkpatrick et al., 2013; Morris and Lancaster, 2006). Contributions are combined with other theories such as institutional entrepreneurship (Ritvala and Granqvist, 2009), diffusion theory (Creed, Scully and Austin, 2002), institutional logics (Waldorff and Greenwood, 2011), and fashion theory (van Veen, Bezemer and Karsten, 2011).

Thematic analysis: From the Scandinavian institutionalist perspective, the concept of translation is closely associated with change in management ideas and 
models. In contrast to the ANT and knowledge-based perspectives, the object of translation is general management ideas, models, and practices. Inspired by Serres (1982) and Latour (1986), Czarniawska and Sevón (2005) propose that translation "attracts attention to the fact that a thing moved from one place to another cannot emerge unchanged: to set something in a new place or another point in time is to construct it anew" (p. 8). Similarly, translation is also defined as "the process in which ideas and models are adapted to local contexts as they travel across time and space" (Lamb and Currie, 2012, p. 219). In this way, translation has both a geometric and semiotic meaning. Spreading constructs are assumed to be stripped of time- and spacebounded features before beginning their travel in translation processes referred to as disembedding (Czarniawska and Joerges 1996) or decontextualization (i.e. "translation from”) (Özen and Berkman, 2007, see also Røvik 2007). The lack of contextual features necessitates varying degrees of modification when the constructs enter a specific organization referred to as processes of reembedding (Ritvala and Granqvist, 2009; Waldorff, 2013b), contextualization (Mazza, Sahlin-Andersson and Pedersen, 2005; Waldorff, 2013b), or reconstruction (i.e. "translation to") (Özen and Berkman, 2007), whereby they acquire a new or modified meaning. Although Czarniawska and Joerges' (1996) original translation model highlights the importance of treating disembedding and reembedding on equal footing, the latter aspect is at the forefront of their own theorizing as well as most subsequent work (e.g. Lamb and Currie, 2012; Morris and Lancaster, 2006; Özen and Berkman, 2007).

Consistent with Latour (1986), translation tends to be understood as a process that leads to heterogeneity and somewhat unpredictable outcomes. In the words of Sahlin and Wedlin (2008, p. 219): “ideas are translated throughout their circulation, and as they evolve differently in different settings, they may not only lead to 
homogenization but also to variation and stratification". For example, Mazza et al. (2005) find that the translation of MBA models into the local contexts of four European universities "clearly" vary, albeit under some degree of homogenizing forces. Kirkpatrick et al. (2013) demonstrate how a generic hospital management model turned out to have different meanings as it was implemented in England, Denmark, France and Italy. However, some studies open up the possibility that translation may display more systematic characteristics and outcomes. Authors reach this conclusion in studies of Total Quality Management (van Veen et al., 2011), health care centers (Waldorff and Greenwood, 2011), and - in contrast to Mazza et al. (2005) - MBA models (Lamb, 2011). Furthermore, some studies explore the possibility of translations following rules that can be identified and described as regularities and patterns (Kirkpatrick et al., 2013; Morris and Lancaster, 2006; Sahlin-Andersson, 1996; Teulier and Rouleau, 2013; Wæraas and Sataøen, 2014). To some extent, this understanding of translation represents a break with the notion that translations unfold unpredictably, resembling more Callon's notion of translations involving convergences and homologies.

The shared characteristic of these contributions is the conception of translation as a change process that leads to modifications in both the spreading construct and the adopting organization. On the basis of this understanding of translation, and with almost no references to ANT and knowledge-based works on translation in organization studies, many studies have focused on how individual organizations pick up, adopt, and incorporate largely conceptual ideas such as lean (Morris and Lancaster, 2006), reputation management (Wæraas and Sataøen, 2014), Total Quality Management (Özen and Berkman, 2007), MBA models (Mazza et al., 2005) and hospital management innovations (Kirkpatrick et al., 2013). Other studies focus on how concepts are translated into different discourses and meanings (Waldorff, 2013b) or 
how generic rational myths translate into specific ones (Zilber, 2006). Again others

have demonstrated how technology-enabled ideas are legitimized and translated into day-to-day practices, also with feedback effects on the broader field as a way to legitimate the innovation as a ready-to-wear concept (Nielsen et al., 2014).

\begin{tabular}{|c|c|c|c|}
\hline & Actor network theory & $\begin{array}{c}\text { Knowledge- based } \\
\text { perspective }\end{array}$ & $\begin{array}{c}\text { Scandinavian } \\
\text { institutionalism }\end{array}$ \\
\hline $\begin{array}{l}\text { Number of } \\
\text { works }\end{array}$ & $\begin{array}{l}28 \\
(22 \text { articles and } 6 \text { book } \\
\text { chapters }\end{array}$ & $\begin{array}{l}8 \\
\text { ( } 8 \text { articles and } 0 \text { book } \\
\text { chapters })\end{array}$ & $\begin{array}{l}36 \\
\text { ( } 20 \text { articles and } 16 \text { book } \\
\text { chapters) }\end{array}$ \\
\hline $\begin{array}{l}\text { Common journal } \\
\text { outlets }\end{array}$ & $\begin{array}{l}\text { Accounting, } \\
\text { Organizations \& } \\
\text { Society (7) } \\
\text { Organization (3) } \\
\text { Organization Studies } \\
\text { (3) }\end{array}$ & $\begin{array}{l}\text { British Journal of } \\
\text { Management (2) } \\
\text { MIS Quarterly (1) } \\
\text { Information and } \\
\text { Organization (1) } \\
\text { Academy of } \\
\text { Management Journal (1) } \\
\text { Organization (1) } \\
\text { Organization Science (1) } \\
\text { Management Decision } \\
\text { (1) }\end{array}$ & $\begin{array}{l}\text { Scandinavian Journal of } \\
\text { Management (4) } \\
\text { Organization Studies (3) } \\
\text { Management Learning } \\
\text { (3) }\end{array}$ \\
\hline $\begin{array}{l}\text { Authors' country } \\
\text { affiliation }\end{array}$ & $\begin{array}{l}\text { UK (14), Denmark (9), } \\
\text { Sweden (6), Australia } \\
\text { (4), France (4), Norway } \\
\text { (3), Canada (3), } \\
\text { Netherlands (2), Italy } \\
\text { (1), Israel (1), US (1), } \\
\text { Germany (1) }\end{array}$ & $\begin{array}{l}\text { UK (8), US (4), France } \\
(3), \text { UK (1) }\end{array}$ & $\begin{array}{l}\text { Sweden (15), Denmark } \\
\text { (11), US (9), UK (7), } \\
\text { Finland (6), Netherlands } \\
\text { (5), Italy (2), Norway (2), } \\
\text { Turkey (2), Israel (2), } \\
\text { Canada (2), Austria (1), } \\
\text { France (1), Germany (1) }\end{array}$ \\
\hline $\begin{array}{l}\text { Preferred } \\
\text { research designs } \\
\text { and methods }\end{array}$ & $\begin{array}{l}\text { Qualitative approaches } \\
\text { (case studies) } \\
\text { Observations, } \\
\text { interviews, document } \\
\text { analysis }\end{array}$ & $\begin{array}{l}\text { Qualitative approaches } \\
\text { (case studies) } \\
\text { Interviews, document } \\
\text { analysis, observations, }\end{array}$ & $\begin{array}{l}\text { Qualitative approaches } \\
\text { (longitudinal) case } \\
\text { studies } \\
\text { Interviews, document } \\
\text { analysis, observations, }\end{array}$ \\
\hline Core concepts & $\begin{array}{l}\text { Power, change, } \\
\text { interests, actor- } \\
\text { networks, macro actors, } \\
\text { interessement, } \\
\text { enrolment, } \\
\text { problematization, } \\
\text { mobilization }\end{array}$ & $\begin{array}{l}\text { Boundaries, boundary } \\
\text { spanning, boundary } \\
\text { objects, peripheries, } \\
\text { transfer, learning }\end{array}$ & $\begin{array}{l}\text { Disembedding, re- } \\
\text { embedding, } \\
\text { transformation, } \\
\text { translation rules, editing } \\
\text { practices, editing rules }\end{array}$ \\
\hline $\begin{array}{l}\text { Other theories } \\
\text { combined with } \\
\text { translation } \\
\text { theory }\end{array}$ & $\begin{array}{l}\text { Accounting theory } \\
\text { Practice theory } \\
\text { Institutional work } \\
\text { Institutional logics } \\
\text { Entrepreneurship } \\
\text { Management fashion } \\
\text { Critical studies }\end{array}$ & $\begin{array}{l}\text { Identity work } \\
\text { Organizational learning }\end{array}$ & $\begin{array}{l}\text { Management fashion } \\
\text { Diffusion theory } \\
\text { Institutional } \\
\text { entrepreneurship } \\
\text { Social movement theory } \\
\text { Institutional logics } \\
\text { perspective }\end{array}$ \\
\hline Research foci & $\begin{array}{l}\text { Moments of translation } \\
\text { and their drivers and } \\
\text { implications. }\end{array}$ & Knowledge translation & $\begin{array}{l}\text { Diffusion and adaptation } \\
\text { of models and ideas. }\end{array}$ \\
\hline
\end{tabular}




\begin{tabular}{|c|c|c|c|}
\hline & $\begin{array}{l}\text { Diffusion and } \\
\text { adaptation of models } \\
\text { and ideas. }\end{array}$ & & \\
\hline $\begin{array}{l}\text { Understanding } \\
\text { of translation }\end{array}$ & $\begin{array}{l}\text { A political process } \\
\text { involving the use of } \\
\text { rhetoric and power. } \\
\text { A gradual change that } \\
\text { occurs to a spreading } \\
\text { construct. }\end{array}$ & $\begin{array}{l}\text { A boundary-spanning } \\
\text { activity undertaken to } \\
\text { ensure the (effective) } \\
\text { flow of critical } \\
\text { information and domain- } \\
\text { specific knowledge } \\
\text { across organizational } \\
\text { boundaries. }\end{array}$ & $\begin{array}{l}\text { The process in which } \\
\text { ideas and models are } \\
\text { adapted to local contexts } \\
\text { (fields or organizations) } \\
\text { as they travel across time } \\
\text { and space }\end{array}$ \\
\hline $\begin{array}{l}\text { Object of } \\
\text { translation }\end{array}$ & $\begin{array}{l}\text { Interests } \\
\text { Management ideas and } \\
\text { practices }\end{array}$ & Knowledge & $\begin{array}{l}\text { Management ideas and } \\
\text { practices }\end{array}$ \\
\hline
\end{tabular}

\section{DISCUSSION}

Our review reveals different perspectives on translation in organizational research but also similarities. All three perspectives focus on the phenomenon of translation, conceptualizing it broadly as a process whereby an object changes from one state to an other as it moves within and across organizational settings. Although the outcome of translations may be unintended (Dooreward and van Bijsterveld, 2001), change does not materialize by coincidence: The perspectives emphasize the active participation of specific actors in translation processes. There are strong parallels between the version of the ANT perspective on translation that primarily emphasizes Latour's model (rather than Callon's four moments) and Scandinavian institutionalism concerning the process and object of translation. The latter perspective also shares many similarities with the knowledge-based perspective on translation: 'Source' and 'target' contexts in the knowledge-based perspective have their conceptual counterparts in the Scandinavian version as contexts in which the processes of disembedding and re-embedding, respectively, occur. The dividing lines between the perspectives are further reduced by the fact that some authors move across the perspectives, relying on one of the approaches in one publication and an other approach in others (e.g. Bergström, 2007; 
Bergström and Diedrich, 2011; Waldorff, 2013a; Waldorff, 2013b), or using several perspectives in one and the same publication (e.g. Frenkel, 2005; Gherardi and Nicolini, 2000).

Despite these similarities, our review confirms that there is more than one 'version' of translation theory in organization studies, as summarized in Table 1. In particular, two observations should be made:

1) While Scandinavian institutionalism is inspired by ANT in general and Latour's model of translation in particular, the 'original' ANT terminology of, and emphasis on, formation of networks and construction of macro actors, negotiations, intrigues, acts of persuasion, and moments of translation tend to be considerably toned down or simply omitted in most of the works classified in the present paper under the Scandinavian perspective. Instead, many Scandinavian institutionalists position themselves in relation to management fashion theory or the American version of institutional theory. They do so either as a way to integrate insights concerning fashion and institutional logics into their framework, or to differentiate from standard expectations of isomorphism being the result of diffusion processes. Similarly, very few works primarily relying on the ANT perspective mention management fashion or institutional fields and logics, and few references to Scandinavian institutionalist works on translation are included. As an illustration, of all the 22 articles classified under the ANT perspective in this review, only three refer to one or more of the 20 articles written from the Scandinavian institutionalist perspective. Furthermore, not more than six of them refer to the constitutive works of Czarniawska (e.g. Czarniawska and Sevón, 1996b, 2005a) or Sahlin (Sahlin and Wedlin, 2008; Sahlin-Andersson, 1996). Conversely, only two of the articles written from the Scandinavian institutionalist perspective refer to one or more of the 22 articles classified under the ANT perspective. 
2) The family ties between the knowledge-based perspective on translation and the other two perspectives are less clear. With some exceptions (Sturdy et al., 2006; Yanow, 2004; see also Gherardi and Nicolini, 2000), as noted, the works subsumed under this perspective tend to maintain a rather instrumental emphasis on translation of knowledge across organizational boundaries, de-emphasizing the (social) constructivist aspects of translation processes for which the ANT and Scandinavian institutionalist perspectives are known. In all the eight knowledge translation articles reviewed in this paper, Latour is mentioned only once, and Czarniawska also only once. Furthermore, together, these works refer to only one article from the Scandinavian institutionalist category reviewed here, and none from ANT perspective.

The lack of cross-referencing and conceptual borrowing between these works is not ideal in terms of developing translation theory further and facilitating progress in the research on translation. Even if works from different camps build on some of the same constitutive works (e.g. Latour and/or Czarniawska), the review points to a potential for enrichment and cross-fertilization. There is a need to map "how, if at all, can varying theoretical traditions be combined" (Spyrionidis et al., 2014, p. 246). We share the view by some authors who have already contributed to cross-fertilization that such combinations are possible (e.g. Bartel and Garud, 2009; Czarniawska and Sevón, 2005b; Frenkel, 2005; Gherardi and Nicolini, 2000). Seeking to extend this possibility further, in the remainder of the paper we discuss various ways in which the three perspectives may complement, enrich, and inform each other.

\section{Combinations and avenues for future research}

We observe that all three perspectives on translation in organizational research identified here can be bridged via a central premise from the ANT perspective; that 
translations have a geometric, semiotic, and political meaning. Borrowing from the knowledge-based perspective, we also divide our focus on translation into a source, brokering, and recipient context from which all three perspectives are seen.

The three perspectives emphasize these meanings and contexts in various ways and degrees. For example, the ANT perspective emphasizes all three meanings, but has its strengths in the political dimension compared to the other two perspectives. The knowledge-based and the Scandinavian institutionalist perspectives both emphasize the geometric and semiotic meaning. Furthermore, the Scandinavian institutionalist perspective has a preference for the source and recipient contexts, and the knowledgebased perspective for the brokering context, while contributions from the ANT perspective emphasize all three contexts. ${ }^{5}$ By subsuming the perspectives under these premises, we recognize that they are sufficiently compatible and, if not "non-identical twins" (Mica, 2013, p. 6, quoting Czarniawska) (or 'triplets'), then at least part of the same family of approaches seeking to understand aspects of the same phenomenon. Of course, some ontological challenges could arise when combining and merging the perspectives because core assumptions differ (Waldorff, 2013a, p. 220). While the ANT and Scandinavian institutionalist perspectives on translation, as noted, build on (social) constructivist approaches, ${ }^{6}$ most of the knowledge-based works reviewed here embrace a positivist approach. Thus, it is their shared focus on translation as well as their relative strengths concerning descriptions and explanations of translation that encourage pragmatic combinations of these perspectives. Figure 2 illustrates how their relative strengths open up possibilities for reciprocal enrichment. 


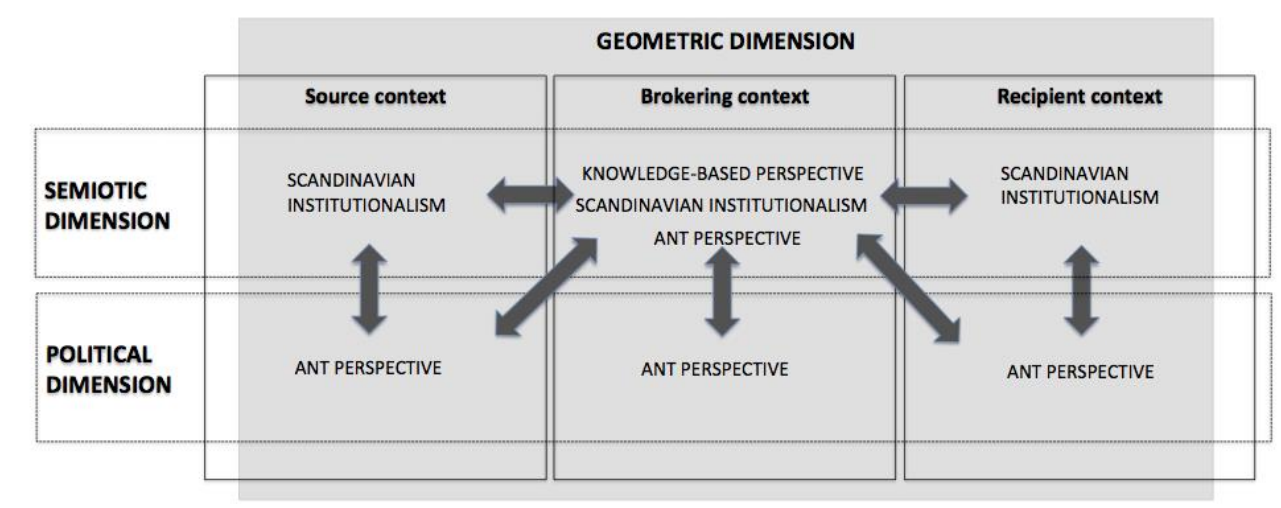

Figure 2: Possibilities for reciprocal enrichment

First, the Scandinavian institutionalist perspective on translation could contribute to the other two perspectives. Neither the ANT nor the knowledge-based perspective on translation says much about the processes whereby an object is transformed into an idea and becomes 'prepared' for diffusion and institutionalization. With its concepts of disembedding and decontextualization, the Scandinavian perspective highlights the possibility of distinct semiotic processes going on in the source context before a construct begins its journey and enters a new context. Thus, future knowledge-based translation research could benefit from, for example, investigating how brokering activities across various organizational contexts are influenced by these processes: To what extent does the work of a broker or "bi-cultural translator", who translates knowledge from a source to a recipient context, depend on the degree of decontextualization that has already occurred in the source context? Which aspects of the disembedding phase are likely to make brokering practices more complicated and which aspects are likely to make them run more smoothly? Similarly, future translation research from an ANT perspective could benefit from understanding how the formation of actor networks in support of a certain object is shaped by decontextualization and disembedding processes. How are problematization, interessement, enrolment, and 
mobilization activities constrained or enabled by these processes? How is translation affected when objects are stripped of their time- and space-bounded features as opposed to when they are not?

In addition, the Scandinavian institutionalist perspective could complement the ANT perspective concerning recipient context issues. Generally, the Scandinavian approach to translation shares the view by Latour that every translation is unique and leads to heterogeneity within organizational fields. However, the recent development within Scandinavian institutionalism of emphasizing translation rules and practices may shift the focus towards homogeneity rather than heterogeneity as the outcome of translation. As noted, this view resonates with Callon's (1980, p. 211) understanding of translation as a practice that involves "convergences and homologies". While effective enrolment may explain the acceptance of a practice within an organization, enrolment may also depend on specific translation rules to make the practice more acceptable. This insight from Scandinavian institutionalism is not pursued within the ANT perspective but could contribute with a more fine-grained understanding of translation processes and outcomes. Thus, are any translation rules involved during the moments of translation? Are they applied in similar or different ways? Do they lead to similar or different outcomes?

Second, the Scandinavian institutionalist and the ANT perspectives could both benefit from adopting insights from the knowledge-based perspective. The Scandinavian institutionalist emphasis on disembedding and re-embedding processes could be informed by knowledge-based notions of 'source', 'target', 'donor', 'recipient', 'boundaries', 'brokers', as well as 'translation effectiveness'. For example, the emphasis on management ideas as emanating from a specific source or donor, handled by specific brokers at the boundaries between two different contexts, and 
directed towards a specific recipient, can be a useful contribution to the geometric emphasis in Scandinavian institutionalism on how ideas circulate in general. As shown by Saka (2004) in her study of the transfer of a work system from a Japanese multinational company to subsidiaries in the UK, the distinction between source and recipient helps direct the attention to specific ends of the dissemination and translation of ideas and practices. In addition, the brokering role as a boundary-spanning activity assigned to specific actors in intra-organizational settings is not really explored in Scandinavian translation research. While Scandinavian institutionalist research points to the important role of consultants, business schools, and management gurus as carriers and translators of management knowledge (Sahlin-Andersson and Engwall, 2002), it has paid little attention to similar processes inside organizations. Thus, knowledge translation theory could enrich such studies by providing a sharper focus on intraorganizational boundaries and translators. Who are the translators, and how do they negotiate between the source and the recipient context in translation processes? How are disembedding and reembedding processes in intra-organizational translation of ideas and practices different from similar processes in inter-organizational translation? How does distance between the source and the recipient affect translations?

Furthermore, in contrast to works written from the knowledge-based perspective, Scandinavian institutionalism is generally not oriented towards the quality or effectiveness of the translation process through which new ideas or practices become (or fail to become) institutionalized. A notable exception is Røvik (2007), who distinguishes between 'good' and 'bad' translations and translators. Inspired by the knowledge-based perspective, and in close resemblance with the concept of "translation capability" developed by Savory (2006), he notes that translation competence is a skill that critically shapes the outcome of translations. It is necessary, he argues, in both 
decontextualization and contextualization processes, because translation processes may fail with insufficient translation competence and thus prevent the movement of a practice from one context to an other. Echoing this rendition of translation theory, we see a potential for the Scandinavian institutionalist perspective to build on the knowledge-based perspective by asking neglected questions such as: Which are the factors that facilitate and determine translation effectiveness? Do translation competence requirements vary depending on the type of idea to be translated? What are the organizational consequences of bad translations? And, what are bad translations? What do they look like and how do we recognize them?

We see a similar potential for the ANT perspective. The concepts of source, target, donor, boundaries, and brokers, which are central to the knowledge-based perspective, have parallel meanings to those of boundary objects, negotiations, intermediators, and mediators, which are central in ANT studies (Latour, 2005). Two studies placed in the residual category in our review have already connected the ANT perspective with these concepts, albeit in varying degrees and ways. Gherardi and Nicolini (2000) address knowledge translation from the ANT perspective, highlighting how knowledge is mediated by technological artifacts ("intermediaries") and translated into a new meaning outside the (source) context in which it was generated. Bartel and Garud (2009) consider the semiotic dimension of translation by combining the ANT perspective with a focus on how innovation narratives serve as boundary objects, travelling and undergoing translations, but also providing coordination, across intraorganizational contexts. Additionally, Nicolini (2011) treats knowledge (or "knowledgeability") as a mediator that travels through time and space and ultimately is retranslated in a new "locale" (i.e recipient context), thus emphasizing both the geometric and semiotic meaning of translation. Extending these works, future studies 
could enrich the ANT perspective by providing an increased focus on the geometric meaning of translation in intra-organizational contexts: How do objects travel from a source to a recipient in organizations, how do their translation depend on the active role of mediators, and which are the characteristics of these contexts and mediators that facilitate or hinder the translation of the object?

Similarly, the concept of translation effectiveness used by authors working from the knowledge-based perspective resonates with the notion of successful or unsuccessful ("failed") translations, which are evoked in ANT studies. From the ANT perspective, a translation is unsuccessful if an actor is unable to mobilize a network in support of a particular object, task, or meaning so that interests are 'aligned' and the object becomes a 'black box' that will not be questioned (Latour, 1987). Organizational research analyzing translation from the ANT perspective does pay some attention to these issues. Alcouffe et al. (2008) contrast the successful translation of an accounting innovation with an unsuccesful one, observing that one of them went through a series of succesful translations and therefore diffused throughout France, while the other did not. Gherardi and Nicolini (2005) report how actors involved in the translation of different innovations encounter both failures and successes in these processes, noting how aspects of specific moments of translation determine success and failure. Building on these insights, an ANT perspective enriched and complemented by the knowledgebased perspective could examine how successful and unsuccessful translations are informed by concepts such as translation effectiveness and translation capability. This does not mean that ANT studies in organizational research on translation should accept the normative focus that effective translations are 'better' translations. However it could mean increased sensitivity to the requirements for successful (or effective) translations, towards which actors are assumed to work. How do translation outcomes end up as 
successes or failures, and why? It could also look at the significance of translation capability: What does translation capability mean in the translation of interests and objects from an ANT perspective? To what extent is translation success dependent on translation capability?

Third, the Scandinavian perspective and the knowledge-based perspective could both be enriched by insights from the ANT perspective. There could be much to gain in Scandinavian institutionalism from an increased focus inspired by ANT on negotiations, power dynamics, and micro-tactics in the translation of managerial ideas and practices. Some authors working from the ANT perspective have already shown that this combination is possible: $\mathrm{Qu}$ and Cooper (2011) examine how actors seek to translate Balanced Scorecard in the pursuit of their own aims. Bergström and Diedrich (2011) show how the translation of corporate downsizing involves power dynamics and the reinforcement of power positions. Additionally, Frenkel (2005) - whom we placed in the residual category in this review - combines the political, semiotic, and geometric dimensions of translation, showing how institutional power structures at the state level in Israel shaped the meaning of Scientific Management and Human Relations. This political meaning of translation should interest Scandinavian institutionalists as well in, for example, studies of how problematization, interessement, enrolment, and mobilization activities matter, of the extent to which institutionalization and deinstitutionalization could depend on or be explained by these processes, and of the implications for a spreading construct when there is inadequate enrolment of actors into a network that supports a specific interpretation of it.

Similarly, the ANT perspective could enrich our understanding of knowledge translation processes by adding a political dimension to brokering practices. This is an under-developed focus area for the knowledge-based perspective. For example, from 
the ANT perspective there are good reasons to assume that brokering and translation activities occurring at the boundary between two contexts are politically charged activities. To what extent is this the case and to what extent do translation brokers promote a specific "world view" (Pawlowski and Robey, 2004) of the object in question? Whose world view is promoted, whose interests are served in the translation of the object, and whose interests are ignored?

Clearly, questions such as these could be valuable for advancing the field of translation research, which undoubtedly has gained momentum in the past decades and already borne much fruit. It could benefit from highlighting links between different perspectives and exploring ways of applying more than one understanding of translation at the same time. New research avenues still remain to be explored if we are to fully take advantage of the richness of translation theory.

\section{CONCLUSION}

In this paper we have profiled translation research by conducting a systematic literature review following the principle of "analyzing the past to prepare for the future" (Webster and Watson, 2002, p. XIII). We identified three perspectives on translation, each with its own distinctive but not necessarily internally consistent characteristics. Second, we suggested a number of ways in which these perspectives may enrich each other. In sum, this paper serves as a review as well as an agenda-setting piece.

In concluding this paper, we highlight the following: We have repeatedly pointed to a lack of cross-references between the three perspectives in the reviewed works, and considered some of their ontological differences. These issues might suggest that the approaches focus on three different phenomena, or are separate or 
incompatible research traditions altogether. We do not believe that this is the case. The perspectives focus on different aspects of translation processes, and do so with different emphases and terminology. We view them as complementary perspectives trying to say something about the same phenomenon: how an object changes from one state to an other within and across organizational settings. As a result, we have - more as a play of words than an actual observation - noted that the perspectives represent three 'translations' of translation theory. This should not be understood literally because we have not studied translation "in action": Our review does not say anything about how different perspectives of translation emerged. It points instead to a variety of outcomes following the 'travel' of translation theory into different organizational research communities, how the conceptualizations of translation differ, and how they are similar.

Furthermore, this review of literature gives no reason to encourage the development of one single theory of translation in organizational research. Such an objective would, in itself, be in disagreement with the notion that local variants emerge as a result of the movement in time and space of objects, ideas, and practices. Instead of seeking forced attempts at integration, a better strategy for achieving progress could be to maintain some degree of distinctiveness within each approach while at the same time learning from the contributions of other perspectives. As a result, no approach should develop in ignorance of the others.

\section{REFERENCES}


Alcouffe, S., N. Berland and Y. Levant (2008). 'Actor-networks and the diffusion of management accounting innovations: A comparative study', Management Accounting Research, 19, pp. 1-17.

Ansari, S., P. C. Fiss and E. J. Zajac (2010). 'Made to fit: How practices vary as they diffuse', Academy of Management Review, 35, pp. 67-92.

Asad, T. (1986). 'The concept of cultural translation in British social anthropology'. In: J. Clifford and G. E. Marcus (eds.), Writing Culture: The Poetics and Politics of Ethnography. pp. 141-164. Berkeley and Los Angeles, CA: University of California Press.

Bartel, C. A. and R. Garud (2009). 'The role of narratives in sustaining organizational innovation', Organization Science, 20, pp. 107-117.

Bergström, O. (2007). 'Translating socially responsible workforce reduction - A longitudinal study of workforce reduction in a Swedish company', Scandinavian Journal of Management, 23, pp. 384-405.

Bergström, 0. and A. Diedrich (2011). 'Exercising social responsibility in downsizing: Enrolling and mobilizing actors at a Swedish high-tech company', Organization Studies, 32, pp. 897-919.

Boxenbaum, E. and J. S. Pedersen (2009). 'Scandinavian institutionalism - a case of institutional work'. In: T. B. Lawrence, R. Suddaby and B. Leca (eds.), Institutional work. Actors and agency in institutional studies of organizations. Cambridge: Cambridge University Press.

Bresman, H. (2013). 'Changing routines: A process model of vicarious group learning in pharmaceutical R\&D', Academy of Management Journal, 56, pp. 35-61.

Bruce, K. and C. Nyland (2011). 'Elton Mayo and the deification of Human relations', Organization Studies, 32, p. 3.

Calás, M. and L. Smircich (1999). 'Past postmodernism? Reflections and tentative directions', Academy of Management Review, 24, pp. 649-671. 
Callon, M. (1980). 'Struggles and Negotiations to Define what is Problematic and what is not: The Socio-logics of Translation'. In: K. Knorr, R. Krohn and R. Whitley (eds.), The Social Process of Scientific Investigation. pp. 197-219. Dordecht: D. Reidel Publishing Co.

Callon, M. (1986). 'Some elements of a sociology of translation: Domestication of the scallops and the fishermen of St. Brieuc Bay'. In: J. Law (ed.) Power, action and belief. A New Sociology of Knowledge? pp. 196-229. London: Routledge and Kegan Paul.

Carlile, P. (2004). 'Transferring, translating, and transforming: An integrative framework for managing knowledge across boundaries', Organization Science, 15, pp. 555-568.

Chiva, R. and J. Alegre (2005). 'Organizational learning and organizational knowledge', Management Learning, 36, pp. 49-68.

Chua, W. F. (1995). 'Experts, Networks and Inscriptions in the Fabrication of Accounting Images - a Story of the Representation of 3 Public Hospitals', Accounting Organizations and Society, 20, pp. 111-145.

Clegg, S. R. (2010). 'The State, Power, and Agency: Missing in Action in Institutional Theory?', Journal of Management Inquiry, 19, pp. 4-13.

Clegg, S. R., M. Kornberger and C. Rhodes (2004). 'Noise, parasites and translation Theory and practice in management consulting', Management Learning, 35, pp. $31-44$.

Creed, W. E. D., M. A. Scully and J. R. Austin (2002). 'Clothes make the person? The tailoring of legitimating accounts and the social construction of identity', Organization Science, 13, pp. 475-496.

Czarniawska, B. (2005). En teori om organisering, Studentlitteratur, Lund.

Czarniawska, B. (2009). 'Emerging institutions: Pyramids or anthills?', Organization Studies, 30, pp. 423-441. 
Czarniawska, B. and T. Hernes (2005). 'Actor-Network Theory and Organizing'. Copenhagen: Copenhagen University Press.

Czarniawska, B. and B. Joerges (1996). 'Travels of ideas'. In: B. Czarniawska and G. Sevón (eds.), Translating organizational change. pp. 13-48. Berlin: deGruyter.

Czarniawska, B. and G. Sevón (1996a). 'Introduction'. In: B. Czarniawska and G. Sevón (eds.), Translating organizational change. pp. 1-12. Berlin: DeGruyter.

Czarniawska, B. and G. Sevón (1996b). 'Translating Organizational Change'. Berlin: deGruyter.

Czarniawska, B. and G. Sevón (2005a). 'Global ideas. How ideas, objects and practices travel in the global economy'. Malmö: Liber.

Czarniawska, B. and G. Sevón (2005b). 'Translation Is a Vehicle, Imitation its Motor, and Fashion Sits at the Wheel'. In: B. Czarniawska and G. Sevón (eds.), Global Ideas: How Ideas, Objects and Practices Travel in the Global Economy. Copenhagen: Liber and Copenhagen Business School.

Dambrin, C. and K. Robson (2011). 'Tracing performance in the pharmaceutical industry: Ambivalence, opacity and the performativity of flawed measures', Accounting Organizations and Society, 36, pp. 428-455.

Dent, M. (2003). 'Managing doctors and saving a hospital: Irony, rhetoric and actor networks', Organization, 10, pp. 107-127.

Djelic, M. L. and K. Sahlin-Andersson (2006). Transnational Governance, Cambridge University Press, Cambridge.

Doolin, B., D. Grant and R. Thomas (2013). 'Translating translation and change: Discourse-based approaches', Journal of Change Management, 13, pp. 251-265. Dooreward, H. and M. van Bijsterveld (2001). 'The osmosis of ideas: An analysis of the integrated approach to IT management from a translation theory perspective', Organization, 8, pp. 55-76. 
Drori, G., M. Höllerer and P. Walgenbach (2014). 'Global Themes and Local Variations in Organization and Management. Perspectives on Glocalization'. New York: London.

Easterby-Smith, M., M. Crossan and D. Nicolini (2000). 'Organizational learning: Debates past, present and future', Journal of Management Studies, 37, pp. 783-796.

Frenkel, M. (2005). 'The politics of translation: How state-level political relations affect the cross-national travel of management ideas', Organization, 12, pp. 275-301.

Gherardi, S. and D. Nicolini (2000). 'To transfer is to transform: The circulation of safety knowledge', Organization, 7, pp. 211-223.

Gherardi, S. and D. Nicolini (2005). 'Actor-networks: Ecology and entrepreneurs'. In: B. Czarniawska and T. Hernes (eds.), Actor-Network Theory and Organizing. pp. 285-306. Copenhagen: Liber \& Copenhagen Business School Press.

Gond, J. P. and E. Boxenbaum (2013). 'The Glocalization of Responsible Investment: Contextualization Work in France and Quebec', Journal of Business Ethics, 115, pp. 707-721.

Gondo, M. B. and J. M. Amis (2013). 'Variations in practice adoption: The role of conscious reflection and discourse', Academy of Management Review, 38, pp. 229-247.

Greener, I. (2006). 'Nick Leeson and the Collapse of Barings Bank: Socio-Technical Networks and the 'Rogue Trader", Organization, 13, pp. 421-441.

Greenwood, R., C. Oliver, K. Sahlin and R. Suddaby (2008). 'Introduction'. In: R. Greenwood, C. Oliver, K. Sahlin and R. Suddaby (eds.), The SAGE handbook of organizational institutionalism. pp. 1-46. Los Angeles, CA: Sage.

Harrison, D. and M. Laberge (2002). 'Innovation, identities and resistance: The social construction of an innovation network', Journal of Management Studies, 39, pp. 497-521. 
Hatim, B. and J. Munday (2004). Translation: An Advanced Resource Book, Routledge, London and New York, NY.

Hernes, T. (2005). 'The organization as nexus of institutional macro actors: The story of a lopsided recruitment case'. In: B. Czarniawska and T. Hernes (eds.), ActorNetwork Theory and Organizing. pp. 112-128. Copenhagen: Liber \& Copenhagen Business Shool Press.

Holden, N. J. and H. F. O. Kortzfleisch (2004). 'Why cross-cultural knowledge transfer is a form of translation in more ways than you think', Knowledge and Process Management, 11, pp. 127-136.

Holmström, J. and D. Robey (2005). 'Inscribing organizational change with information technology'. In: B. Czarniawska and T. Hernes (eds.), Actor-Network Theory and Organizing. pp. 165-187. Copenhagen: Liber \& Copenhagen Business School Press.

Høyer, K. (2009). 'Informed Consent: The Making of a Ubiquitous Rule in Medical Practice', Organization, 16, pp. 267-288.

Jensen, T., J. Sandström and S. Helin (2009). 'Corporate Codes of Ethics and the Bending of Moral Space', Organization, 16, pp. 529-545.

Johnson, B. and J. Hagström (2002). 'Policyspridning som översättning: En fallstudie av svensk metadon-behandling mot heroinnarkomani', Nordiske Organisasjonsstudier, 4, pp. 26-59.

Johnson, B. and J. Hagström (2005). 'The translation perspective as an alternative to the policy diffusion paradigm: The case of the Swedish methadone maintenance treatment. ', Journal of Social Policy, 34, pp. 365-388.

Kelemen, M. (2000). 'Too much or too little ambiguity: The language of Total Quality Management', Journal of Management Studies, 37, pp. 483-498. 
Kirkpatrick, I., B. Bullinger, F. Lega and M. Dent (2013). 'The translation of hospital management models in European Health systems: A framework for comparison', British Journal of Management, 24, pp. S48-S61.

Knights, D., F. Murray and H. Willmott (1993). 'Networking as knowledge work: A study of strategic interorganizational development in the financial services industry', Journal of Management Studies, 30, pp. 975-995.

Lamb, P. (2011). 'Eclipsing adaptation: The translation of the US MBA model in China', Management Learning, 43, pp. 217-230.

Lamb, P. and G. Currie (2012). 'Eclipsing adaptation: The translation of the US MBA model in China', Management Learning, 43, pp. 217-230.

Latour, B. (1986). 'The powers of association'. In: J. Law (ed.) Power, action and belief. London: Routledge.

Latour, B. (1987). Science in Action - How to Follow Scientists and Engineers Through Society, Harvard University Press, Cambridge, MA.

Latour, B. (2005). Reassembling the Social: An introduction to Actor-Network Theory, Oxford University Press, Oxford.

Lee, N. and J. Hassard (1999). 'Organization unbound: Actor-Network theory, research strategy and institutional flexibility', Organization, 6, pp. 391-404.

Lok, J. (2011). 'Institutional logics as identity project', Academy of Management Journal, 53, pp. 1305-1335.

MacPherson, A. and O. Jones (2010). 'Strategies for the development of International Journal of Management Reviews', International Journal of Management Reviews, 12, pp. 107-113.

Madsen, D. Ø. and K. Slåtten (2015). 'The balanced scorecard: Fashion or virus?', Administrative Sciences, 5, pp. 90-124.

Maguire, S. and C. Hardy (2009). 'Discourse and deinstitutionalization: The decline of DDT', Academy of Management Journal, 52, pp. 148-178. 
Maguire, S., C. Hardy and T. B. Lawrence (2004). 'Institutional entrepreneurship in emerging fields: HIV/Aids treatment advocacy in Canada', Academy of Management Journal, 47, pp. 657-689.

Mazza, C., K. Sahlin-Andersson and J. S. Pedersen (2005). 'European constructions of an American model - Developments of four MBA programmes', Management Learning, 36, pp. 471-491.

McLean, C. and J. Hassard (2004). 'Symmetrical absence/symmetrical absurdity: Critical notes on the production of actor-network accounts', Journal of Management Studies, 41, pp. 493-519.

Mennicken, A. (2008). 'Connecting worlds: The translation of international auditing standards into post-Soviet audit practice', Accounting Organizations and Society, 33, pp. 384-414.

Merminod, V. and F. Rowe (2012). 'How does PLM technology support knowledge transfer and translation in new product development? Transparency and boundary spanners in an international context', Information and Organization, 22, pp. 295-322.

Mica, A. (2013). 'From Diffusion to Translation and Back. Disembedding-Re-embedding and Re-invention in Sociological Studies of Diffusion', Polish Sociological Review, 1, pp. 3-19.

Miles, J. A. (2012). Management and Organization Theory, Jossey-Bass, San Francisco, CA. Morris, T. and Z. Lancaster (2006). 'Translating management ideas', Organization Studies, 27, pp. 207-233.

Mouritsen, J., H. T. Larsen and P. N. D. Bukh (2001). 'Intellectual capital and the 'capable firm': narrating, visualising and numbering for managing knowledge', Accounting Organizations and Society, 26, pp. 735-762.

Mueller, F. and A. Whittle (2011). 'Translating management ideas: A discursive devices analysis', Organization Studies, 32, pp. 187-210. 
Munir, K. A. (2004). 'Discontinuity and After: The Social Dynamics of Technology Evolution and Dominance', Organization Studies, 25, p. 561.

Nicolini, D. (2010). 'Medical innovation as a process of translation: A case from the field of telemedicine', British Journal of Management, 21, pp. 1011-1026.

Nicolini, D. (2011). 'Practice as the site of knowing: Insights from the field of telemedicine', Organization Science, 22, pp. 602-620.

Nielsen, J. A., L. Mathiassen and S. Newell (2014). 'Theorization and translation in information technology institutionalization: Evidence from Danish home care', MIS Quarterly, 38, pp. 165-186.

Özen, S. and Ü. Berkman (2007). 'Cross-national reconstruction of managerial practices: TQM in Turkey', Organization Studies, 28, pp. 825-851.

Pawlowski, S. and D. Robey (2004). 'Bridging user organizations: Knowledge brokering and the work of information technology professionals', MIS Quarterly, 28, pp. 645-672.

Qu, S. Q. and D. J. Cooper (2011). 'The role of inscriptions in producing a balanced scorecard', Accounting Organizations and Society, 36, pp. 344-362.

Quist, J. and A. Hellström (2012). 'Process Management as a Contagious Idea: a Contribution to Røvik's Virus-Inspired Theory', International Journal of Public Administration, 35, pp. 901-913.

Ritvala, T. and N. Granqvist (2009). 'Institutional entrepreneurs and local embedding of global scientific ideas-The case of preventing heart disease in Finland', Scandinavian Journal of Management, 25, pp. 133-145.

Robson, K. (1991). 'On the Arenas of Accounting Change - the Process of Translation', Accounting Organizations and Society, 16, pp. 547-570.

Røvik, K. A. (1998). Moderne organisasjoner : trender i organisasjonstenkningen ved tusenårsskiftet, Fagbokforl., Bergen-Sandviken. 
Røvik, K. A. (2007). Trender og translasjoner. Ideer som former det 21. århundrets organisasjoner, Universitetsforlaget, Oslo.

Røvik, K. A. (2011). 'From fashion to virus: An alternative theory of organizations' handling of management ideas', Organization Studies, 32, pp. 631-653.

Sahay, S., J. Sæbø and J. Braa (2013). 'Scaling of HIS in a global context: Same, same, but different', Information and Organization, 23, pp. 294-323.

Sahlin, K. and L. Wedlin (2008). 'Circulating ideas: Imitation, translation and editing'. In: R. Greenwood, C. Oliver, K. Sahlin and R. Suddaby (eds.), The SAGE Handbook of Organizational Institutionalism. London: Sage.

Sahlin-Andersson, K. (1996). 'Imitating by editing success: The construction of organizational fields'. In: B. Czarniawska and G. Sevón (eds.), Translating organizational change. pp. 69-93. New York: Walter de Gruyter.

Sahlin-Andersson, K. and L. Engwall (2002). The expansion of management knowledge, Stanford Business Books, Stanford, CA.

Saka, A. (2004). 'The cross-national diffusion of work systems: The translation of Japanese operations in the UK', Organization Studies, 25, pp. 209-228.

Savory, C. (2006). 'Translating knowledge to build technological competence', Management Decision, 44, pp. 1052-1075.

Scheuer, J. D. (2008a). 'Convergent and divergent processes of change in organizations. Exploring change as translation in the encounter of idea and practice'. In: S. Scheuer and J. D. Scheuer (eds.), The Anatomy of Change. A Neoinstitutional Perspective. pp. 107-137. Copenhagen: Liber and Copenhagen Business School Press.

Scheuer, J. D. (2008b). 'Intervention, implementation, and translation as metaphors of change in healthcare and public sector organizations'. In: S. Scheuer and J. D. Scheuer (eds.), The Anatomy of Change: A Neo-institutionalist Perspective. pp. 139-180. Copenhagen: Copenhagen Business Press. 
Scheuer, S. and J. D. Scheuer (2008). 'The Anatomy of Change: A Neo-institutionalist Perspective'. Copenhagen: Copenhagen Business Press.

Serres, M. (1982). Hermes: Literature, science, philosophy, Johns Hopkins University Press, Baltimore, MD.

Sevón, G. (1996). 'Organizational imitation in identity transformation'. In: B. Czarniawska and G. Sevón (eds.), Translating organizational change. pp. 49-67. New York: Walter de Gruyter.

Spyrionidis, D., G. Currie, S. Heusinkveld, K. Strauss and A. Sturdy (2014). 'New developments in translation research', British Journal of Management, 16, pp. $245-248$.

Straus, S. E., J. Tetroe and I. D. Graham (2009). 'Knowledge translation in Health Care: Moving from Evidence to Practice'. Oxford: Wiley-Blackwell.

Sturdy, A. (2009). 'Popular Critiques of Consultancy and a Politics of Management Learning?', Management Learning, 40, pp. 457-463.

Sturdy, A., M. Brocklehurst, D. Winstanley and M. Littlejohns (2006). 'Management as a (self) confidence trick: Management ideas, education, and identity work', Organization, 13, pp. 841-860.

Teulier, R. and L. Rouleau (2013). 'Middle Managers' Sensemaking and Interorganizational Change Initiation: Translation Spaces and Editing Practices', Journal of Change Management, 13, pp. 308-337.

Thorpe, R., C. Eden, J. Bessant and P. Ellwood (2011). 'Rigour, relevance and reward: Introducing the knowledge translation value-chain', British Journal of Management, 22, pp. 440-431.

Tranfield, D., D. Denyer and P. Smart (2003). 'Towards a methodology for developing evidence-informed management knowledge by means of systematic review', British Journal of Management, 14, pp. 207-222. 
van Veen, K., J. Bezemer and L. Karsten (2011). 'Diffusion, translation and the neglected role of managers in the fashion setting process: The case of MANS', Management Learning, 42, pp. 149-164.

Vidgen, R. and T. McMaster (1996). 'Black boxes, non-human stakeholders and the translation of IT through mediation'. In: W. Orlikowski, G. Walsham, M. R. Jones and J. I. DeGross (eds.), Information Technology and Changes in Organizational Work. pp. 250-271. London: Chapman \& Hall.

Wæraas, A. and H. L. Sataøen (2014). 'Trapped in conformity? Translating reputation management into practice', Scandinavian Journal of Management, 30, pp. 242253.

Waldorff, S. B. (2013a). 'Accounting for organizational innovations: Mobilizing institutional logics in translation', Scandinavian Journal of Management, 29, pp. 219-234.

Waldorff, S. B. (2013b). 'What is the meaning of public sector health? Translating discourse into new organizational practices', Journal of Change Management, 13, pp. 283-307.

Waldorff, S. B. and R. Greenwood (2011). 'The dynamics of community translation: Danish health-care centers'. In: C. Marquis, M. Lounsbury and R. Greenwood (eds.), Research in the Sociology of Organizations. pp. 113-142. Emerald Group Publishing.

Webster, J. and R. T. Watson (2002). 'Analyzing the past to prepare for the future: Writing a literature review', MIS Quarterly, 26, pp. XII-XXIII.

Whitley, E. A. (1999). 'Understanding participation in entrepreneurial organizations: some hermeneutic readings', Journal of Information Technology, 14, pp. 193-202. Whittle, A. and A. Spicer (2008). 'Is actor network theory critique?', Organization Studies, 29, pp. 611-629. 
Woolgar, S., C. Coopmans and D. Neyland (2009). 'Does STS Mean Business?',

Organization, 16, pp. 5-30.

Yanow, D. (2004). 'Translating Local Knowledge at Organizational Peripheries', British

Journal of Management, 15, pp. S9-S25.

Zilber, T. B. (2006). 'The work of the symbolic in institutional processes: Translations of rational myths in Israeli high tech', Academy of Management Journal, 49, pp. 281303.

\footnotetext{
${ }^{1}$ In our review, we identified eight papers published in Organization Studies between 2004 and 2011. Among the last three, all published in 2011, Bergström and Diedrich (2011) and Bruce and Nyland (2011) referred to one of the five previous ones, whereas Mueller and Whittle (2011) referred to none.

${ }^{2}$ Even when the inspiration comes from the same source, different translation models, or versions of translation theory, may emerge. This is confirmed by Doolin, Grant and Thomas (2013) who identify six approaches to translation and change (engagement, endless transmutations, struggle, transgression, and colonization) and by Scheuer (2008a) who distinguishes between seven translation models within the Scandinavian institutionalist literature (the idea model by Czarniawska and Joerges (1996); the editing model by Sahlin-Andersson (1996); the imitation model by Sevón (1996); the model developed by Røvik (1998); Czarniawska's (2005) model of action nets; Johnson and Hagström's (2002) communication model; and finally Scheuer's own model of association. These versions or models emphasize different aspects of translation and are related through their respective connection to an overarching perspective on translation.

${ }^{3}$ In fact, it could be argued that the literature on practice variation is an example of how translation theory has been "made to fit" a North American neo-institutional context (we thank one of the anonymous reviewers for pointing this out to us).

${ }^{4}$ Although the perspective is known as Scandinavian in foundation, contributions are found in different parts of the world. This is clearly reflected in the variation in the authors' country affiliations. Authors working out of a total of 14 different countries (e.g. UK, US, Sweden, Finland, Turkey, Italy, Canada and Israel) have participated in writing the 36 works.

${ }^{5} \mathrm{We}$ are aware that the original thinking by Latour and Callon does not include the concepts of source, target, and recipient (although negotiations and "brokering" across boundaries are a vital aspect of the actor-network theory). However, our paper is not a review of these original contributions, it is a review of how current organizational scholars use the ANT perspective. The interest of some of them in, for example, diffusion from an ANT perspective (e.g. Alcouffe et al., 2008; Gond and
} 
Boxenbaum, 2013) motivates the inclusion of concepts emphasizing the geometric meaning of translation such as source, brokering, and recipient contexts.

${ }^{6}$ The ANT perspective adopts a constructivistic ontology, which assumes that the social and the material world co-construct knowledge of reality. Scandinavian

institutionalism, on the other hand, builds upon a social constructivist ontology that highlights how belief systems and knowledge of reality are taken for granted as a result of social interaction. 